\title{
Relationships Between Ecosystem Services: Comparing Methods for Assessing Tradeoffs and Synergies
}

\author{
Améline Vallet ${ }^{a b c}$, Bruno Locatelli ${ }^{b c}$, Harold Levrel ${ }^{a}$, Sven Wunder ${ }^{c}$, Ralf Seppelt ${ }^{\mathrm{d}}$, \\ Robert J. Scholes ${ }^{\mathrm{e}}$, Johan Oszwald ${ }^{\mathrm{f}}$ \\ a CIRED, AgroParisTech, Cirad, CNRS, EHESS, Ecole des Ponts ParisTech, Université Paris-Saclay, 94130 Nogent-sur- \\ Marne, France \\ ${ }^{\mathrm{b}}$ CIRAD, Research Unit on Forests and Societies, University of Montpellier, F-34398 Montpellier, France \\ ${ }^{c}$ CIFOR, Av. La Molina 1895, La Molina, Lima, Peru \\ ${ }^{d}$ UFZ - Helmholtz Centre for Environmental Research, Department of Computational Landscape Ecology, Permoserstr. 15, \\ 04318 Leipzig, Germany \\ ${ }^{e}$ Global Change Institute, University of the Witwatersrand, Wits, 2050, South Africa \\ ${ }^{\mathrm{f}}$ Université Rennes 2, Unité Mixte de Recherche CNRS 6554-LETG Rennes COSTEL, 35043 Rennes, France
}

Manuscript published in Ecological Economics:

Vallet A., Locatelli B., Levrel H., Wunder S., Seppelt R., Scholes R.J., Oszwald J., 2018. Relationships between ecosystem services: Comparing methods for assessing tradeoffs and synergies. Ecological Economics 150: 96-106. doi:10.1016/j.ecolecon.2018.04.002

\section{Highlights}

- The literature applies different methods to assess relationships between ecosystem services

- In a case study in Costa Rica, all tested methods showed similar tradeoffs between food and carbon

- Methods showed different levels of sensitivity in detecting relationships between services

- For most pairs of services, tested methods led to different interpretations, either complementary or contradictory 


\section{Abstract}

Understanding the interactions between the multiple ecosystem services (ES) which can be delivered from a single landscape is essential. Most studies on ES relationships use spatial or temporal statistical analysis (for example: correlations between services). Methods from microeconomic theory have recently received attention for describing ES relationships. The nature and intensity of ES relationships can be assessed by fitting a production possibility frontier that indicates the maximum amount of one ES that can be produced by landscape, for different levels of another ES. This study estimates production frontiers empirically, and compares the ES relationships insights gained this way with those inferred from correlation approaches. InVEST software was used to model and map the provision of six ES in the Reventazón watershed in Costa Rica. Spatial and temporal ES correlation patterns were analyzed for four observed land uses/land covers (LULC). Production frontiers were constructed using a set of 32 simulated scenarios. Production frontier was the most sensitive method for detecting ES relationships. The nature and intensity of ES relationships revealed depended on the analytic methods used. In comparison with correlations, the production frontier approach provided additional information relating to tradeoff intensity and Pareto efficient LULC configurations.

\section{Introduction}

Over the past 50 years, population growth and economic development have increased the global demand for ecosystem provisioning services, for example food, fibers and timber. Conversion of land to satisfy these needs has increased pressures on ecosystems, generally leading to a decrease in regulating services (e.g. climate, erosion and floods) and cultural services (e.g. recreation and education) (Bennett and Balvanera, 2007; Carpenter et al., 2009). Because of competition for land and natural resources, increasing the supply of one ecosystem service (ES) may result in reducing the supply of others (Minang et al., 2014; Seppelt et al., 2014; Turner et al., 2013). Reconciling multiple conflicting objectives of ecosystem management and dealing with ES tradeoffs are major challenges of sustainable development and sustainability science (Birkhofer et al., 2015; Carpenter et al., 2009; Grêt-Regamey et al., 2016).

Landscape managers have direct and indirect effects on ES supply levels (Haase et al., 2012). Their decisions often involve tradeoffs between ES, deliberate when they reflect explicit 
choices or unintentional when knowledge is lacking (Hauck et al., 2013; Martinez-Harms et al., 2015; Turner et al., 2013). Recent publications highlight the different uses of ES knowledge in decision-making processes and distinguish between decisive, technical and informative uses (Laurans et al., 2013; McKenzie et al., 2014; Schleyer et al., 2015). With the two former uses, knowledge about ES relationships contributes to defining and evaluating policies. For example, it may help allocate financial and human capitals to the land management in a way that improves multi-functionality and reduces competition between services now and in the future (de Groot et al., 2010; Lautenbach et al., 2015; Turner et al., 2013). Informative use of ES relationship knowledge is also important to raise awareness about environmental problems and foster dialogue, debate and negotiation between stakeholders (McKenzie et al., 2014).

The word "tradeoff" has been used to describe different types of compromises occurring from provision to benefit and management of ES in the literature (Cord et al., 2017; Lee and Lautenbach, 2016; Mouchet et al., 2014; van Wijk et al., 2016): ranging from compromises between ES (Bennett et al., 2009) and between generations (Rodríguez et al., 2006), to compromises between ES provision and demand (Mouchet et al., 2014; TEEB, 2010) or between beneficiaries of ES (Martín-López et al., 2012). The analysis of tradeoffs between ES (i.e. the focus of our study) has received much more attention than other dimensions of tradeoffs (Turkelboom et al., 2017). It has been conflated in an inconsistent and misleading way to the concepts of "ES relationships", "ES interactions" and "ES associations" in literature (Birkhofer et al., 2015; Mouchet et al., 2014; Seppelt et al., 2011). Mouchet et al. (2014) observed that the word "tradeoff" should not be used to describe static negative associations between ES (like spatial congruence, spatial concordance, co-occurrence or overlap of ES), but reserved for associations repeated in time and space. Others called for a better distinction between two types of relationships between ES, as defined by Bennett et al. (2009) (Birkhofer et al., 2015; Cord et al., 2017; Seppelt et al., 2011). Direct relationships between ES involve causal relationships between ES, while indirect relationships are based on correlations due to biophysical or socioeconomic drivers (Bennett et al., 2009; Birkhofer et al., 2015; Seppelt et al., 2011). Only relationships falling in the first category are truly "ES interactions" ("ES associations" could be used for the second category) (Birkhofer et al., 2015). Consequently, "ES relationships", "ES associations" and "ES interactions" should not be used in an interchangeable way as it is common in literature currently. In this paper, following Bennett et al. (2009), we distinguish "ES associations" (i.e. spatial concordance, co-occurrence or overlap of ES) from "ES interactions" (i.e., truly causal interactive mechanisms between ES), both being different types 
of the broader category "ES relationships". Without necessarily endorsing the language but following the general use in the literature, we define "synergies" simply as ES positive associations (i.e. without considering that synergies may produce combined effects greater than the sum of the separate effects) and tradeoff as negative associations. Also following general use, we distinguish between three types of relationships: tradeoff (in which one service decreases while another one increases); synergy (in which both services increase or decrease together); and no effect (Bennett et al., 2009; Jopke et al., 2015; Lee and Lautenbach, 2016).

Various methods exist to assess ES relationships, including participatory methods, empirical approaches, econometric tools, simulation and optimization models (Cord et al., 2017; Deng et al., 2016; Lee and Lautenbach, 2016; Mouchet et al., 2014; van Wijk et al., 2016). They are linked to the framing of ES relationships, and their choice depends on the problem and the decision context (Martín-López et al., 2014). For example, looking at ES relationships through spatial co-occurrence (whether ES are in high supply or low supply in the same places in landscape) is useful for defining management priorities (e.g. conservation of hotspots or restoration of coldspots) (Dittrich et al., 2017) or characterizing landscape multi-functionality (e.g. identifying the "bundles" of ES which typically co-occur) (Raudsepp-Hearne et al., 2010). But it might be irrelevant for assessing how managing the land to increase the provision of one ES will affect other ES (Seppelt et al., 2011). There is a need to clarify which types of issues each method can help to resolve, taking into account their range of application and underlying hypothesis (Gasparatos, 2010). Few studies have done so explicitly (but see: Mouchet et al., 2014; Tomscha and Gergel, 2016; Zheng et al., 2014).

In this paper, we ask the following question: Do different assessment methods lead to different interpretations and conclusions about ES relationships? We apply three different methods spatial and temporal correlations between ES pairs and production possibility frontiers - for assessing ES relationships in the upper part of the Reventazón watershed in Costa Rica, compare their outcomes and implications, and discuss the assumptions and applicability of each of the methods. 


\section{Analytical Approaches to Ecosystem Service Relationships}

We selected three bivariate methods for assessing ES relationships, commonly used in the literature (Deng et al., 2016; Lee and Lautenbach, 2016): (1) Static spatial correlations; (2) Spatial correlations of temporal variations; (3) Two-dimension production possibility frontiers. Multivariate methods including multidimensional production frontiers (Ruijs et al., 2013), PCA (e.g. Clec'h et al., 2016; Lavorel et al., 2011; Maes et al., 2012; Vigl et al., 2016), factor analysis (e.g. Qiu and Turner, 2013) and cluster analysis (e.g. Haines-Young et al., 2012; RaudseppHearne et al., 2010) have been used for analyzing relationships between more than two ES at a time (and to identify bundles of ES in the case of PCA, factor analysis and cluster analysis) (Cord et al., 2017; Lee and Lautenbach, 2016), but we restricted our analysis to bivariate methods whose results can be easily displayed as graphs and compared.

Spatial correlation approaches compute the statistical correlations between the levels of two ES (ES1, ES2) across multiple spatial units. ES values are obtained for a given time, which makes this a static analysis (Fig. 1). Spatial correlations are the most commonly used methods to describe ES relationships (Lee and Lautenbach, 2016). After the first analyses of ES static spatial correlations and overlaps in California by Chan et al. (2006), many studies have adopted this approach (for example: Egoh et al., 2008; Jopke et al., 2015; Raudsepp-Hearne et al., 2010; Turner et al., 2014; Willemen et al., 2010). Various metrics can be used to express the correlation between ES1 and ES2 and test its significance, depending on the normality of the distribution of ES1 and ES2 and the presence of spatial auto-correlation. The standard procedure relies on $t$-tests and Pearson's correlation coefficient in the case of ES assumed to have with bivariate normal distributions (Chan et al., 2006; Raudsepp-Hearne et al., 2010). This approach can be adapted to non-normal distributions by using Spearman's rank correlation coefficient instead (Egoh et al., 2008; Locatelli et al., 2014; Willemen et al., 2010). Both parametric and non-parametric tests of significance can be corrected to take into account spatial autocorrelation (Casalegno et al., 2013; Gos and Lavorel, 2012). Static spatial correlation studies have been criticized because they omit landscape history, an important factor in understanding ES relationships (Tomscha and Gergel, 2016), and because they often present ES spatial correlations as interactions, even when they are not; they are simply evidence of nonrandom associations (Bennett et al., 2009; Cord et al., 2017). 

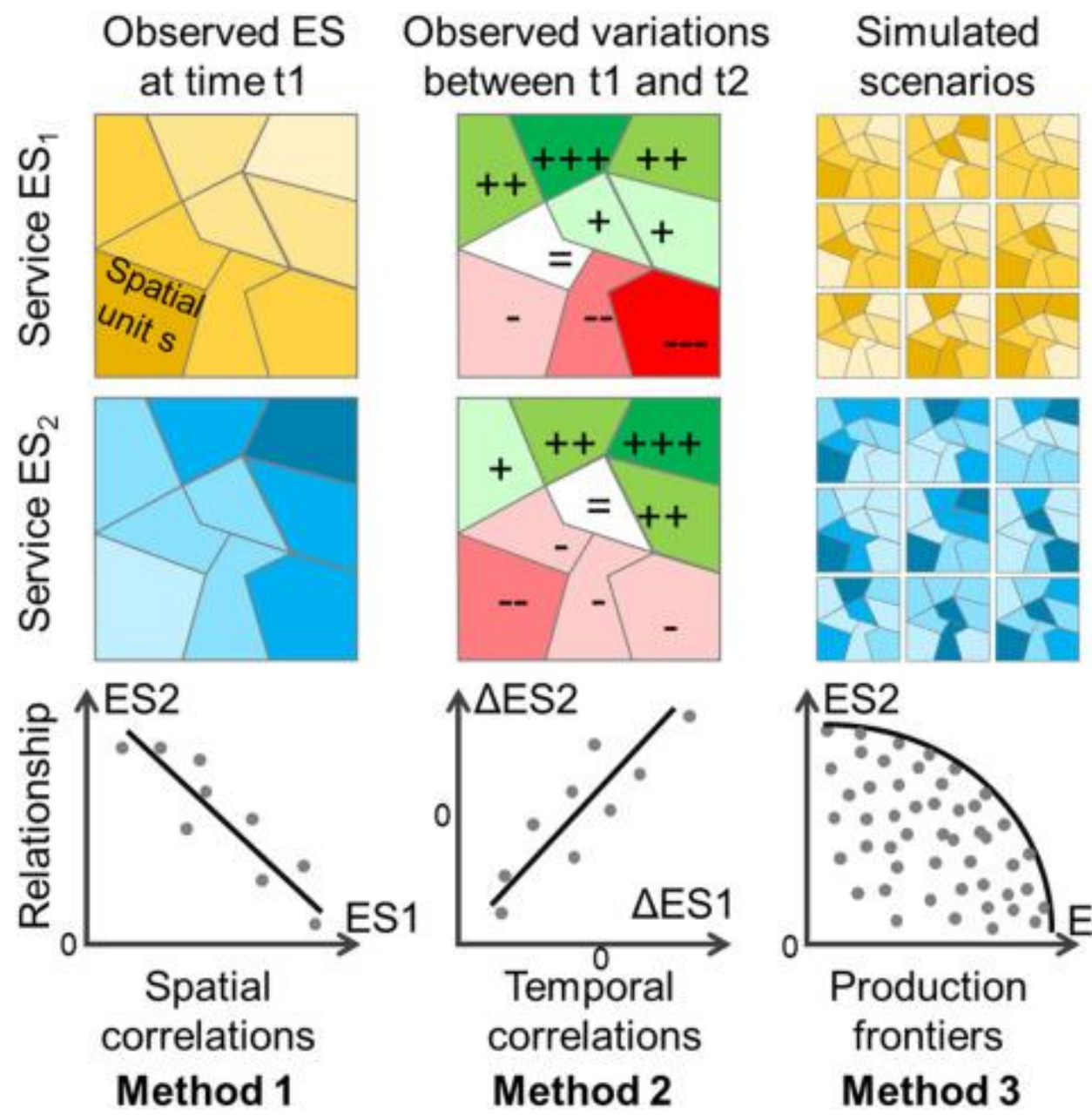

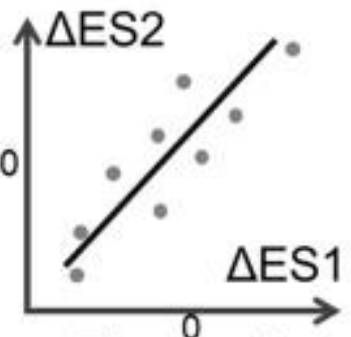

Temporal correlations

Method 2
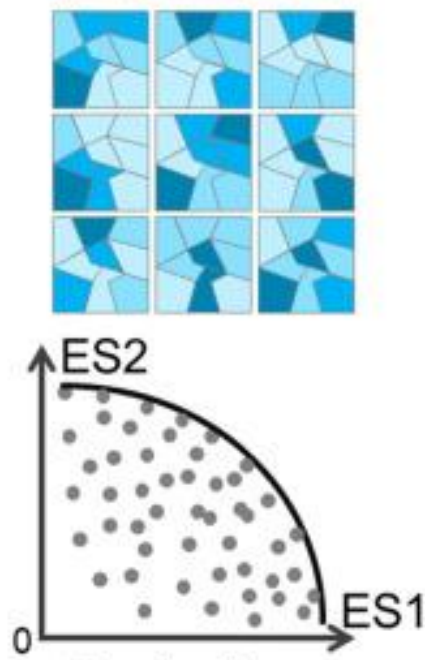

Production frontiers

Method 3

Fig. 1. Graphical representation of the three methods selected for analyzing relationships between ES. In the left and right columns, yellow and blue colors represent ES1 and ES2 values respectively, with darker cells representing higher values. In the middle column, cell shading and signs represent temporal changes in ES1 and ES2, from increases (green and plus sign) to decreases (red and minus sign). Each dot in the biplots in the lower panel corresponds to a spatial unit, and the lines are either best-fit regressions (Methods 1 and 2) or a convex production frontier (Method 3). (For interpretation of the references to colour in this figure legend, the reader is referred to the web version of this article.)

Less frequently applied are methods integrating ES temporal dynamics by analyzing historical datasets (Renard et al., 2015; Tomscha and Gergel, 2016; Zheng et al., 2014); as few studies have data on ES over both time and space (Cord et al., 2017; Dittrich et al., 2017; Locatelli et al., 2017). Static spatial correlations can be calculated at different dates in order to detect changes in ES relationships overtime (Renard et al., 2015; Tomscha and Gergel, 2016). Alternately, the correlation can be performed on the difference in ES supply at two times, called "the spatial correlation of temporal variation", or the "change-over-time approach" (Tomscha and Gergel, 2016) or "correlation analysis between the amounts of changes in ES" (Zheng et 
al., 2014). For conciseness, we refer to it as "temporal correlation" in the rest of this paper (Fig. 1). It can also be computed using either Pearson or Spearman correlation coefficients.

In parallel, welfare economics and production theory have inspired frameworks to describe relationships between ES (Bekele et al., 2013; King et al., 2015; Lester et al., 2013; Smith et al., 2012; Wossink and Swinton, 2007). In these frameworks, the set of production possibilities describes all combinations of multiple ES levels that can be accommodated within a landscape given its structure, natural capital and management inputs (human labor, technology, etc.) (Cavender-Bares et al., 2015; Kline and Mazzotta, 2012). The boundary of the set is comprised of combinations such that one ES cannot be improved without reducing the others (Nelson et al., 2008; White et al., 2012) (Fig.1). Such combinations often called "Pareto optimal" or "Pareto efficient" (Bekele et al., 2013; Lester et al., 2013; Ruijs et al., 2013), although strictly speaking the Pareto criterion applies to people, not to services or goods (Varian, 2010). The terms "Pareto optimality" and "Pareto efficiency" are used interchangeably in the literature, even though the former is often used as a normative criterion indicating desirable situations, while the latter implies a more neutral description in positive economics (Berthonnet and Delclite, 2014). For this reason we use "Pareto efficiency"; often just "efficiency" for conciseness, acknowledging that we always talk of allocative (Pareto) efficiency and not productive efficiency (i.e. production at the lowest cost). The boundary of the set is known as the production possibilities frontier, also called the "efficiency frontier" (Cavender-Bares et al., 2015; Polasky et al., 2008). For conciseness, we refer to this as the "production frontier" in the following.

Production frontiers represent the set of efficient configurations, defined as landscape configurations that bring efficient supply of all ES according to the Pareto criterion. Although production frontiers can be used with more than two ES or dimensions (for an example of fourdimension frontier see Ruijs et al., 2013), applications to pairs of ES are the most common because they are theoretical simple, easily displayed graphically, and a first step before analyzing multivariate relationships (Chan et al., 2006; Lee and Lautenbach, 2016; RaudseppHearne et al., 2010). The slope of the frontier at a point represents the marginal ES2 loss when ES1 increases, or vice-versa (Cavender-Bares et al., 2015). Any combination located inside the frontier (rather than on the frontier) is sub-efficient regarding both services considered (Lester et al., 2013). 
The construction of production frontier is a two-step procedure (Hauer et al., 2007). First, ES are assessed across a set of management options (as large and diverse as possible) using qualitative information, theoretical models, quantitative models, or empirical data, depending on data available (King et al., 2015; Lester et al., 2013). Second, efficient combinations for each ES pair are identified using Pareto-dominance criteria or statistical estimators (Ruijs et al., 2013). Analyzing all possible management scenarios is in most cases practically impossible because of data and computational requirements, particularly if ES models are not automatically connected to the computer tools for building scenarios (Kline and Mazzotta, 2012; Seppelt and Voinov, 2003, Seppelt and Voinov, 2002; Yapo et al., 1998). Even though production frontiers depend on scenario selection and too few scenarios could lead to ambiguous conclusions (Kline and Mazzotta, 2012), using a set of a limited size is acceptable if it includes sufficiently diverse and contrasted scenarios close to the putative frontier (i.e. adding more scenarios to the analysis will not improve substantially the production frontier) (Lester et al., 2013). Another approach uses smart sampling strategies to improve scenario selection, for example constraint optimization (Hauer et al., 2007; Lester et al., 2013), Latin hypercube sampling (Manache and Melching, 2004) or genetic algorithms (Groot et al., 2012; Lautenbach et al., 2013; Seppelt and Voinov, 2002). However, such sampling strategies often ignore that some scenarios are biophysically or socioeconomically unrealistic.

The production frontier approach provides information about ES relationships beyond that yielded by either static or temporal correlations. It shows how current configurations differ from the efficient ones or could be improved, and therefore it can be used to discuss stakeholder preferences for different efficient landscape configurations (Bekele et al., 2013; CavenderBares et al., 2015; Lester et al., 2013). Although all points on the frontier are equally efficient in terms of ES provision, they may not be equally desirable to stakeholders or the society (King et al., 2015; Kline and Mazzotta, 2012). The most desirable landscape configuration depends on the values given by stakeholders to different ES (Cavender-Bares et al., 2015; King et al., 2015; Lester et al., 2013). It can be identified by combining the production frontier with indifference curves that represent the preferences of a given stakeholder or social group for ES (i.e. how much they would trade off one ES in exchange for another) (Cavender-Bares et al., 2015; King et al., 2015; Kline and Mazzotta, 2012; Lester et al., 2013). Some challenges have been raised regarding the application of production possibility framework, such as the difficulty of identifying plausible landscape configurations and ES combinations, and the rather abstract nature of discussions about landscape optimality and efficiency (Kline and Mazzotta, 2012). 
The three methods use different ES variables (values at a single time for methods 1 and 3 vs. values at two times or more for method 2) and different landscape configurations (one observed landscape configuration for method 1; two configurations of the same landscape at two dates for method 2; and a large number of hypothetical landscape configurations for method 3). All approaches describe different aspects of ES relationships (tradeoffs and synergies), that can be compared. Thus, one should not expect the three methods to come to the same conclusions. For instance, in the simple example shown in Fig. 1, methods 1 and 3 suggest tradeoffs between ES, whereas method 2 suggests synergies. The three methods might result in different patterns of ES relationships.

\section{Study Site}

We applied our analytical framework to the Volcanic Central Talamanca Biological Corridor in Costa Rica, an area of $740 \mathrm{~km}^{2}$ (1.4\% of Costa Rica) on the Caribbean slopes of Central Cordillera, comprising the upper catchments of the Reventazón and Pacuare rivers (Fig. 2, with data from Hijmans et al., 2005; ITCR, 2004; NASA LP, 2011). Altitude ranges from 268 to $3087 \mathrm{~m}$ a.s.l. The climate is tropical humid, with strong variation of rainfall depending on elevation (mean annual rainfall is of $2700 \mathrm{~mm}$ in Turrialba), irregularly distributed throughout the year due to Caribbean influences (Imbach et al., 2010). LULC is dominated by secondary and primary forests covering $48 \%$ of the area in 2008 , mostly in the southern and north-eastern periphery (Bosselmann, 2012; Brenes Pérez, 2009). The rest of the area is made up of agricultural mosaics including pasture for dairy and cattle farming, coffee and sugarcane. During the 1986-2008 period, LULC changes in the study site consisted of an expansion of forests and crops (including sugarcane) and a decline in pastures and coffee plantations, as a response to socio-economic drivers including changes in agricultural prices and urbanization (Brenes Pérez, 2009; Carmona and DeClerck, 2012; Vallet et al., 2016). The Reventazón watershed is an important supplier of ES, including agricultural products. It produces $30 \%$ of the milk and meat in the country, $85 \%$ of the potato and onion crop, and $23 \%$ of flowers and ornamental plants for export (PREVDA, 2008). It is also highly strategic for hydroelectricity, with $27 \%$ of national production capacity (Locatelli et al., 2011). 


\section{Legend}

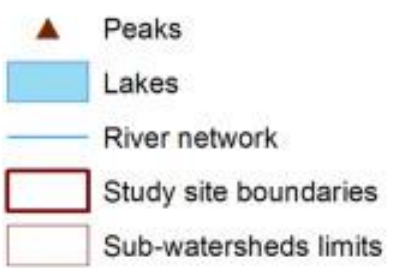

Human settlements

- Major towns

- Towns

- Villages

Protected Areas

VII National Parks

Forest Reserves

Digital Elevation Model

Altitude (m)

$3087 \mathrm{~m}$

$268 \mathrm{~m}$

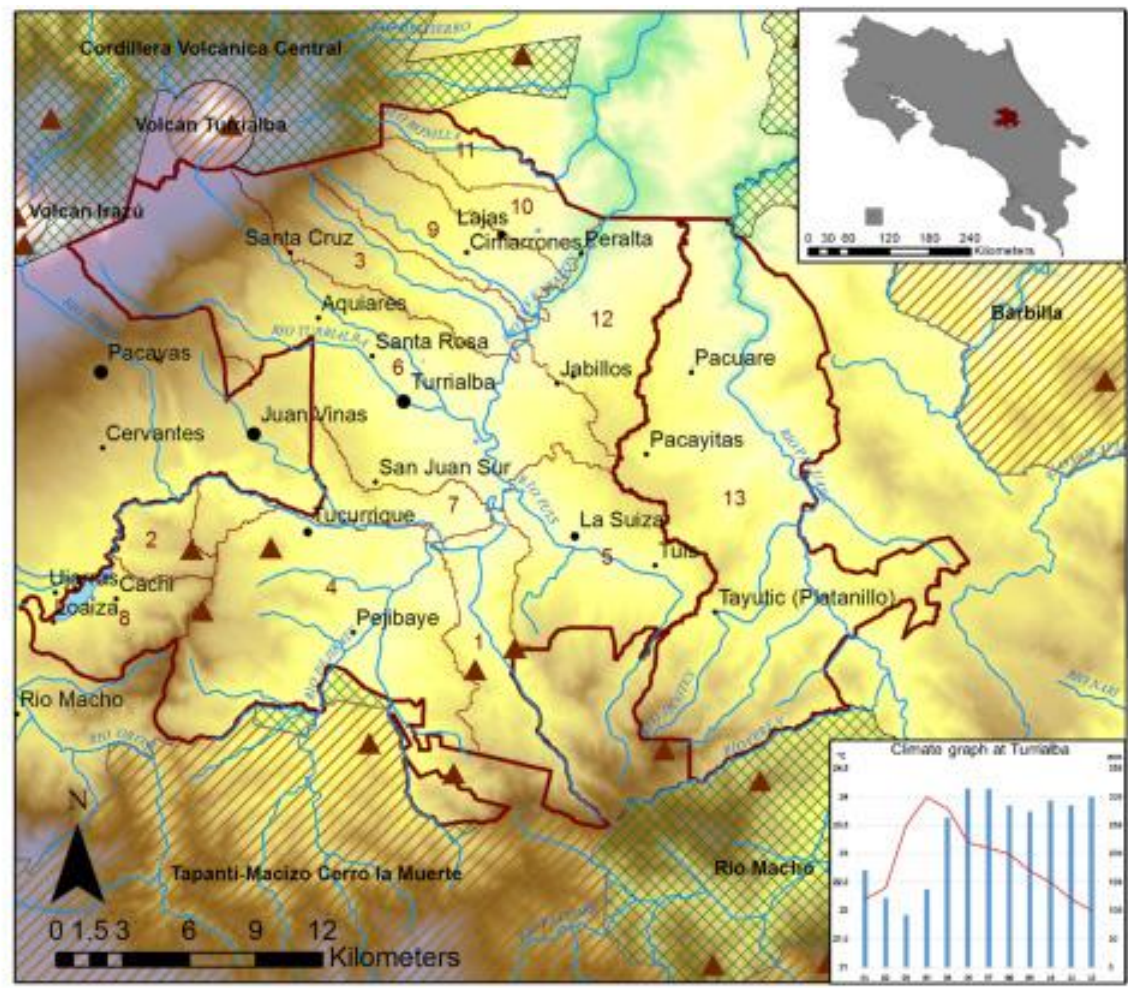

Fig. 2. Location of the study site in Costa Rica.

This area is particularly relevant for analyzing relationships between ES. Multiple ES are produced by coffee production systems in the area, managed as agroforests with shading tree species that contribute to both conservation of biodiversity (Caudill et al., 2015) and regulation of soil and climate (Avelino et al., 2012; Carmona and DeClerck, 2012). Previous studies highlighted the capacity of this area to provide simultaneously multiple ES with diverging trends over time, suggesting the existence of tradeoffs (Estrada Carmona, 2009; Vallet et al., 2016).

\section{Materials and Methods}

We selected six ES for analysis: one provisioning ES (agricultural production, called "A" hereafter) and five regulating ES - carbon storage ("C", capacity to store carbon and thus mitigate climate change), water yield ("W", quantity of freshwater runoff per year), nitrogen and phosphorus retention ("N" and "P", contribution of the ecosystem to retaining nutrients on the land rather than allowing them to be carried off in runoff) and sediment retention ("S", capacity to prevent soil erosion). These ES are of particular importance in the study area because of the economic importance of agriculture and water-related activities (such as 
hydropower production) and the susceptibility of soils to erosion. Cultural services are also important in this landscape, but we did not have data to assess them.

We modeled the six ES using estimates of prices and yields for each agricultural product for the provisioning service, and the InVEST software for the regulating ES. InVEST consists of a suite of spatially-explicit models that use LULC maps, biophysical and economic data to quantify and map various ES provided by landscape in biophysical or economic terms (Cabral et al., 2016; Levrel et al., 2017; Nelson et al., 2009; Tallis and Polasky, 2009). The choice of InVEST was motivated by its extensive use to evaluate the impact of land-use change on ES levels and to provide information about tradeoffs between competing landscape objectives to decision-makers (for example: Nelson et al., 2009; Polasky et al., 2011). Models, specific data sources and the assumptions used for modeling the six ES selected are detailed in Vallet et al. (2016).

We modeled the six ES produced under four observed sequential landscape configurations of $30 \mathrm{~m}$ resolution (using satellite images and orthorectified photographs for 1986, 1996, 2001 and 2008, see Brenes Pérez (2009) for details) and 32 simulated (hypothetical) landscape configurations. The 32 LULC scenarios applied slope and altitude constraints for some landuse classes and assumed various LULC proportions and spatial distributions, either random or clustered (see SI1 and SI2 for details on scenarios creation and characteristics).

For all landscape configurations, the ES maps produced by InVEST were log-transformed where necessary to meet the assumptions of normality required by Pearson's correlation coefficient test of significance (except carbon sequestration, which already presented a normal distribution) (following Jopke et al. (2015)). Mean pixel values were then extracted for each of the 13 sub-watersheds of the study site, and rescaled to $0-1$ by dividing by the maximum value over all sub-watersheds and all landscape configurations. Sub-watersheds were delineated using a $30 \mathrm{~m}$ resolution Digital Elevation Model derived from the ASTER GDEM project (NASA LP, 2011) and a river network shapefile (ITCR, 2004), using the ArcHydro tools of ArcGIS (ESRI, 2012).

For static spatial correlations, we calculated the Pearson correlation coefficients between pairs of ES (sub-watershed level) at the four dates. For the temporal correlations, we calculated the variations of each ES between two consecutive dates (1986-1996, 1996-2001, 2001-2008) and between the start and end of the whole period studied (1986-2008). We computed the Pearson 
correlation coefficients between variations of ES on the different time periods, including for the whole period studied (i.e. the correlation between variations that happened during the 19862008 period). We choose to use Pearson's correlation coefficient for spatial and temporal correlations since it is the most frequently used approach in literature.

We graphically represented the production possibility set of each pair of ES by plotting ES values in all landscape configurations (four observed and 32 simulated) against one another. We obtained fifteen scatterplots, based on 468 observations (i.e. 13 sub-watersheds in 36 landscape configurations). In each scatterplot, the production frontier consisted in the set of efficient ES combinations identified using the Pareto dominance criterion and joined by a line (See SI3 for mathematical details). The shape and orientation of the point cloud in each scatterplot, and the proximity of points to each other also provide graphical information on the existence, strength and nature of a relationship (Cleff, 2014; LeBlanc, 2004). To describe scatterplots, we adopted an approach similar to the graphical analyses conducted by Jopke et al. (2015) on ES bagplots, and considered three important features for the analysis of ES relationships: distribution of ES values (dispersion of the scatterplot), distribution asymmetry (scatterplot shape) and correlation (scatterplot direction). Distribution patterns in the cloud of points were detected by computing a shape index I from envelope area and perimeter of the cloud of points (Eq. (1)). This index ranges between 0 for elongated clouds (linear pattern of association) of ES pairs and 1 for circular shapes (no association). We arbitrarily chose to consider shapes elongated when $I<0.75$.

$$
I=\frac{4 \pi \text { Area }}{\text { Perimeter }^{2}}
$$

The envelope of cloud of points was computed using alpha-shape, a computational geometry algorithm that draws straight-line graphs around points and is a generalization of convex hulls (Edelsbrunner et al., 1983). This envelope was graphically represented in each scatterplot. The portion of the envelope that also corresponded to the production frontier was not represented in case it involved non Pareto efficient combinations. In the cases where a linear pattern of association was detected with the shape index, the orientation of the scatterplot informed on the nature of the relationship: synergy for scatterplots oriented from lower left to upper right and tradeoff for higher left to lower right orientation (Jopke et al., 2015). 
All analyses used R software v3.3.2 (R Core Team, 2016), with the following packages: raster v2.3-24 (Hijmans et al., 2015) for creating scenarios, emoa v0.5-0 (Mersmann, 2012) for detecting Pareto efficient combinations, alphahull v2.1 (Pateiro-Lopez and Rodriguez-Casal, 2016) and geometry v0.3-6 (Barber et al., 2015) for drawing envelopes and computing shape index, and ggplot2 v2.2.1 for creating graphics (Wickham et al., 2016).

\section{Results}

\subsection{Spatial Correlations}

Spatial correlations were similar for all the four dates considered (see SI4). In 2008 (the most recent date here selected as representative), four out of the 15 ES pairs were significantly correlated (Fig. 3 left), two positively (P with A and N) and two negatively (C with A and P). Spatial correlations could be interpreted in terms of ES relationships: for example, the A-C negative correlation showed that places with high agricultural production had low carbon storage, and vice-versa, suggesting a tradeoff between these ES. In contrast, N and P were positively correlated, in other words, places with high nitrogen retention had also high phosphorus retention, suggesting a synergy between them.

\section{Spatial correlations in 2008}

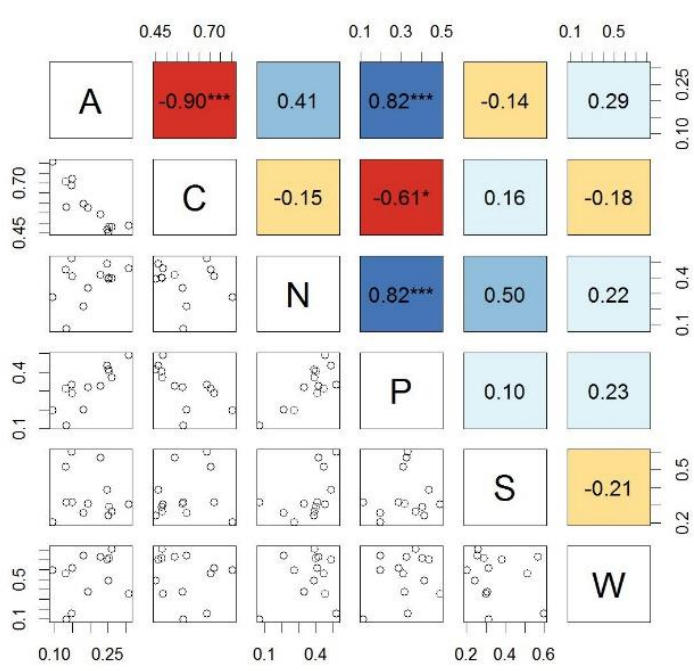

\section{Temporal correlations for the $1986-2008$ period}

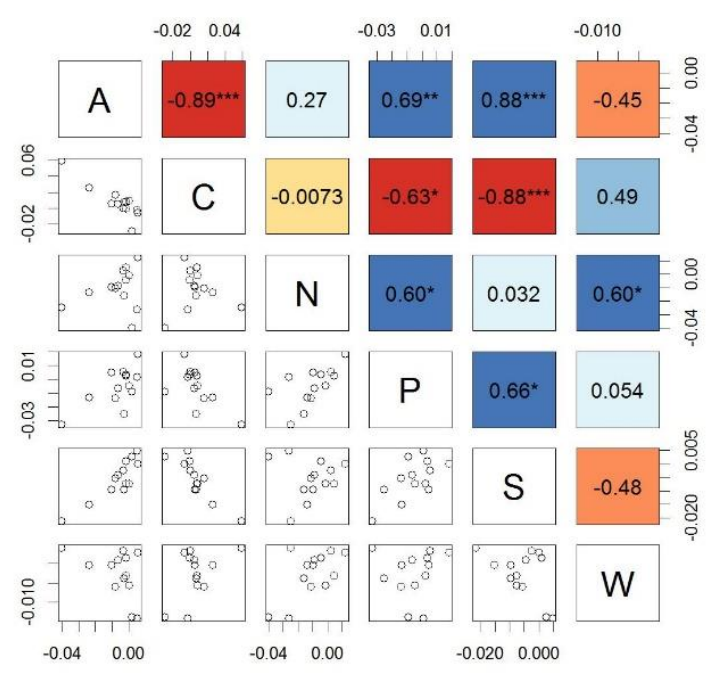

Fig. 3. Spatial correlation (left) and temporal correlation (right) between ES pairs. These matrixes are symmetric grids. The names of ES are on the diagonal (A: agricultural production, C: carbon sequestration, N: nitrogen retention, P: phosphorus retention, $\mathrm{S}$ : sediment retention, W: water yield). Each cell bellow the diagonal shows a bivariate scatterplot for each pair of services (service $j$ is plotted against service $i$ in the $i j$ th cell of the lower 
triangle of the grid). Points represent mean values of ES $i$ and $j$ at the level of sub-watersheds (468 observations in total). Each cell above the diagonal shows Pearson correlation coefficients for each pair of ES, its colour describes the nature and intensity of the correlation (red for negative correlations and blue for positive correlations) and asterisks show the significance degree ( $* * *$ for $p<0.001, * *$ for $p<0.01, *$ for $p<0.05$ ). (For interpretation of the references to colour in this figure legend, the reader is referred to the web version of this article.)

\subsection{Temporal Correlation}

For the whole period (1986-2008), 8 of the 15 possible pairs were significantly correlated (Fig. 3 right), five positively (A-P, A-S, N-P, N-W, and P-S) and three negatively (A-C, C-P, and CS). For the shorter time intervals, fewer significant correlations were found (see SI5). A positive temporal correlation indicated that the pair of ES changed in the same direction in the same places, while a negative correlation showed they changed in opposite directions for given places. For example, the negative correlation between A and C (Fig. 3 right) meant that in places where the agricultural production increased between 1986 and 2008, carbon storage decreased, suggesting a tradeoff between these two ES, a finding which concurs with method 1. In contrast, nitrogen and phosphorus retention were positively correlated by this method: in other words, places with increasing nitrogen retention also increased phosphorus retention, suggesting a synergy between these two ES, also in agreement with the first method (Table 1). 
Table 1. Comparison of the interpretation of ES relationships among the three methods.

\begin{tabular}{|l|l|l|l|}
\hline $\begin{array}{l}\text { Pairs of } \\
\text { ES }\end{array}$ & $\begin{array}{l}\text { Spatial } \\
\text { correlations }\end{array}$ & $\begin{array}{l}\text { Temporal } \\
\text { correlations }\end{array}$ & Production Frontiers \\
\hline Tradeoffs in observed and hypothetical landscapes \\
\hline A-C & Tradeoff & Tradeoff & Strong tradeoff (cloud and curve) \\
\hline C-P & Tradeoff & Tradeoff & Tradeoff (cloud and curve) \\
\hline C-S & Neutral & Tradeoff & Tradeoff (cloud and curve) \\
\hline Synergies in observed and hypothetical landscapes \\
\hline A-P & Synergy & Synergy & $\begin{array}{l}\text { Synergies (cloud) but tradeoff between Pareto } \\
\text { efficient combinations (curve) }\end{array}$ \\
\hline N-P & Synergy & Synergy & $\begin{array}{l}\text { Synergy (cloud) and only one Pareto efficient } \\
\text { combination }\end{array}$ \\
\hline A-S & Neutral & Synergy & $\begin{array}{l}\text { Synergies (cloud) but weak tradeoff between } \\
\text { Pareto efficient combinations (curve) }\end{array}$ \\
\hline P-S & Neutral & Synergy & $\begin{array}{l}\text { Synergy (cloud) and only one Pareto efficient } \\
\text { combination }\end{array}$ \\
\hline Clear relationships in hypothetical landscapes but not in observed landscapes \\
\hline C-N, C-W & Neutral & Neutral & Weak tradeoff (cloud and curve) \\
\hline N-S & Neutral & Neutral & $\begin{array}{l}\text { Synergy (cloud) and only one Pareto efficient } \\
\text { combination }\end{array}$ \\
\hline Absence of relationships & or unclear findings \\
\hline N-W & Neutral & Synergy & $\begin{array}{l}\text { Neutral (cloud) but weak tradeoff between Pareto } \\
\text { efficient combinations (curve) }\end{array}$ \\
\hline P-W, S-W & Neutral & Neutral & $\begin{array}{l}\text { Neutral (cloud) but weak tradeoff between Pareto } \\
\text { efficient combinations (curve) }\end{array}$ \\
\hline A-W & Neutral & Neutral & $\begin{array}{l}\text { Neutral (cloud) and only one Pareto efficient } \\
\text { combination }\end{array}$ \\
\hline A-N & Neutral & $\begin{array}{l}\text { Synergies (cloud) but weak tradeoff between } \\
\text { Pareto efficient combinations (curve) }\end{array}$ \\
\hline
\end{tabular}

\subsection{Production Frontiers}

The clouds of points showed a wide diversity of shapes over all ES pairs (Fig. 4). All pairs involving water yield (W) showed dispersed clouds of points, with shape indices over 0.75 . Other pairs formed elongated point clouds (shape index $<0.75$ ), where the main axis of the cloud had either positive or negative slope (respectively / and $\backslash$ categories in Fig. 4). Four pairs had only a single Pareto efficient combination (A-W, N-P, N-S, P-S). In other ES pairs, production frontiers varied from short (A-N, A-P, A-S, N-W, P-W, S-W) to long (A-C, C-N, C-P, C-S, C-W), and were convex (A-C, A-P) straight (C-N, C-P, C-S) or concave (A-N, A-S, C-W, N-W, P-W, S-W). 


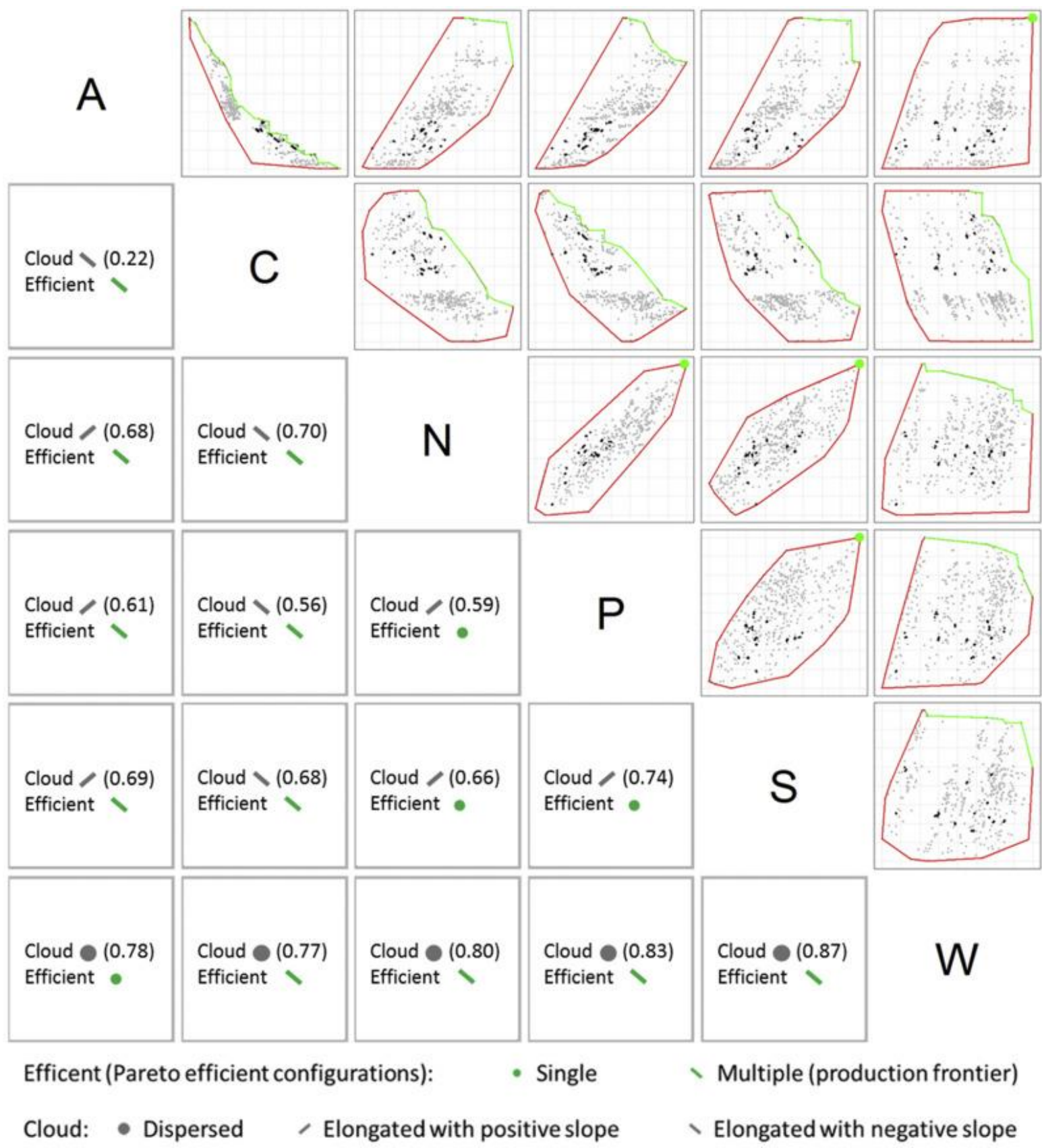

Fig. 4. Results of the production frontier approach. This matrix must be read the same way as in Fig. 3. Dots represent mean values of ES at the level of sub-watersheds (468 observations in total), normalized between 0 and 1. Black dots represent the 4 observed scenarios and grey ones represent the 32 hypothetical scenarios. Production frontiers are shown in green and non Pareto efficient portions of the cloud envelopes in red. When only one efficient ES combination is identified, it is represented by a green dot. Each cell below the diagonal shows an analysis of plots based on the shape of the cloud (shape index is given in parentheses) and number of Pareto efficient combinations. (For interpretation of the references to colour in this figure legend, the reader is referred to the web version of this article.)

The interpretation of clouds of production possibilities in terms of ES relationships was more complicated than for the first two methods, because it must consider several features of the 
plots: the dispersion of the cloud of points; the orientation of the cloud and the number of Pareto efficient combinations (Table 1). Dispersed, apparently random clouds suggested an absent or weak relationship between ES. For example, the A-W plot suggested that high agricultural production could be associated with almost any water yield. In contrast, elongated clouds suggested there was a strong relationship. For instance, in the A-C plot, high levels of agricultural production were always associated with low level of carbon storage, suggesting a tradeoff. The N-P plot was also an elongated cloud, but in this case the orientation of the cloud was positive: in other words, where nitrogen retention was high, so was phosphorus retention, and vice-versa, suggesting a synergy.

For some ES pairs, there was a single Pareto efficient combination, where both ES had their highest levels. This situation generally occurred for ES pairs that were in synergies according to the point cloud analysis (e.g. N-P), but not always (cf SI6 for a graphical explanation). For example, the A-W pair had one single Pareto efficient combination but no clear and strong ES relationship according to the cloud shape. In contrast, some plots showed an extended production frontier where the shape of the cloud suggested synergy (e.g. A-N) or noninteractive ES (e.g. P-W).

For other ES pairs, multiple Pareto efficient combinations were identified. When cloud analysis revealed a tradeoff, the shape of the production frontiers provided information about the intensity of the tradeoff: intense (convex curve, also called concave upward or convex downward) or moderate (concave curve, also called concave downward or convex upward). For example, the A-C production frontier had negative slope and a convex shape, which suggested a strong tradeoff: from an efficient configuration with high carbon (C) and low agricultural production (A), increasing A would strongly decrease $\mathrm{C}$ (and vice-versa with high $\mathrm{A}$ and low $\mathrm{C}$ : increasing $\mathrm{C}$ would strongly reduce $\mathrm{A}$ ). In contrast, the concave shape of the $\mathrm{C}-\mathrm{N}$ production frontier suggested a moderate tradeoff, because increasing one ES would only moderately decrease the other.

Real landscapes (black dots in Fig. 4) were far from Pareto efficient combinations (green curves or dots) for most ES pairs. The only exception was with the A-C pair: almost all observed landscapes were bordering the section of the production frontier with high carbon values and low agricultural production. The levels of individual ES were in general lower in observed landscapes than in simulated scenarios (grey dots in Fig. 4), except in the case of carbon 
sequestration (mostly high $\mathrm{C}$ in observed landscapes) and water yield (some high $\mathrm{W}$ in observed landscapes).

\section{Discussion}

\subsection{Comparing Interpretations}

Even though there is limited research on ES relationships in Central America (Balvanera et al., 2012), tradeoffs between erosion control and biodiversity have been found in our study site (Carmona and DeClerck, 2012) and synergies between carbon sequestration and water-related services have been identified at the national scale (Locatelli et al., 2014). We did not observe a clear relationship between carbon and water, which might suggest that scale has an effect on the nature and intensity of the relationships detected.

The three methods all concluded that the relationship between agricultural production and carbon sequestration shows a tradeoff. This result is consistent with other studies analyzing relationships between those two ES (Haase et al., 2012; Maes et al., 2012; Raudsepp-Hearne et al., 2010). Other ES showed either no relationships with agricultural production (for example water yield) or synergies (for example phosphorus retention). This can be explained by the models we used to quantify ES: the simplified representation of water and nutrient processes in InVEST and the absence of model validation may limit confidence with which we can interpret ES relationships (Bagstad et al., 2013; Nemec and Raudsepp-Hearne, 2012). Although most studies on ES identify tradeoffs between regulating and provisioning ES (Lee and Lautenbach, 2016), our results point out that correlative associations between food production and regulating services should not be automatically identified as interactions, or generalized to other landscapes without caution (Swallow et al., 2009).

The three methods are increasingly sensitive for detecting ES relationships in the order of their presentation here: spatial correlations, temporal correlations, production frontiers. For most ES pairs, if the first method leads to a specific interpretation about ES relationships, the same interpretation is found with the second and third methods; but the first method leads to fewer interpretations on synergies or tradeoffs than subsequent methods (Table 1). For tradeoffs, production frontiers enable a precise description of tradeoff intensity, which correlations do not allow. 
The two first methods, both based on observed landscape configurations lead to similar conclusions for most pairs of ES (Table 1). The exceptions are the four pairs for which method 1 does not show significant correlations, whereas method 2 does. For example, there is no significant spatial correlation between A and S; but temporal analysis shows that places where agricultural production increases also show increased sediment retention, suggesting a synergy. Other studies have found that static approaches (method 1) detect fewer relationships than dynamic approaches (Tomscha and Gergel, 2016; Zheng et al., 2014). For four ES pairs, method 3 detects ES relationships (tradeoffs with $\mathrm{C}-\mathrm{N}$ and $\mathrm{C}-\mathrm{W}$, synergies with $\mathrm{A}-\mathrm{N}$ and $\mathrm{N}-\mathrm{S}$ ), while other methods do not. These results suggest that, because production frontiers are based on a large number of simulated scenarios, including combinations not observed in past to current landscapes, they can detect more ES relationships than approaches based on observed landscapes.

The hypothetical nature of the landscapes scenarios generated in order to construct production frontiers explains some differences between findings: given that landscape changes are usually slow and in continuity with previous configurations, observed landscapes are generally similar one to another (i.e. the black dots in Fig. 4 were clustered). Therefore, methods relying solely on observed data offer only a narrow glimpse of the full range of potential ES values. In contrast, production frontiers consider a broad range of ES levels, revealing unsuspected relationships between ES. Several publications observe that in order to be useful to decisionmaking, scenarios must account for the uncertain nature of the future, and incorporate surprises and discontinuities (Duinker and Greig, 2007; IPBES, 2016; Peterson et al., 2003; Seppelt et al., 2013; Tourki et al., 2013). This requires large sets, with as complete a range of configurations as possible.

None of the three methods really deal with ES interactions; they reveal ES relationships from which interactions can be inferred but not proven. In addition, the observed ES relationships are partly explained by how InVEST models the services, rather than by real-world ES interactions. Establishing ES interactions requires a better understanding of their underlying causes and the relationships between ES and global drivers (land-use change, climate change, etc.). By using associations or correlations as proxies for causal relationships, we fall into the fallacy that correlation proves causation. There is a risk of suggesting active interaction where the correlation is either spurious or due to a common underlying driver (Cord et al., 2017). A refined typology of ES interactions, based on the one proposed by Bennett et al. (2009), but 
elaborated to consider the shape (convex or concave) as well as the slope of the relationship (positive or negative), can be applied to suggest the mechanisms and possible interactions behind the reveal relationships. Rigorous establishment of causal mechanisms for interactions will require experimental work and innovative approaches, not just correlative studies (Cord et al., 2017).

\subsection{Explaining and Interpreting Correlations}

For method 1 (spatial correlation), ES levels depend in many cases on shared underlying factors, such as LULC. For example, the observed strong tradeoff between agricultural provision and carbon sequestration results from the fact that InVEST models for carbon sequestration and agricultural production are based on simple look-up tables with LULC with high agricultural production having low carbon sequestration and vice-versa (except for coffee agroforestry systems). As a consequence, those ES cannot be observed at the same time in one given LULC. The same reason explains the synergy between nitrogen and phosphorus retention: LULC with high retention capacity for nitrogen had usually high retention capacity for phosphorus.

For method 2 (temporal correlation), ES relationships are interpreted as the consequences of underlying processes, such as land-use changes. In the study site, LULC changes are dominated by changes in forests and agricultural areas. As forests have no agricultural production and high carbon sequestration (and agricultural areas have the opposite), those ES show opposite trends over time (Vallet et al., 2016). Other ES pairs show surprising results: for instance, agricultural production and sediment retention are positively correlated using method 2, even though they are un-correlated with method 1. Because the drivers of the spatial distribution of ES (hydrological connectivity, altitude, climate, etc.) can be different to drivers of their temporal evolution (LULC change, urbanization), the approaches can identify different ES relationships.

\subsection{The Value and Constraints of the Production Frontier Approach}

Interpreting production frontiers leads to new insights on ES relationships, but at the price of complexity, since several lines of evidence must be simultaneously considered. Production frontiers are also sensitive to outlier ES combinations. For example, some ES pairs show either a single Pareto efficient combination (e.g. A-W) or a concave production frontier (e.g. S-W); but the plots suggest that the identified efficient combinations depend on one or a few points. Adding or removing one scenario in the plot could transform a production frontier into a single 
Pareto efficient combination or vice-versa. For this reason, the short production frontiers of some ES pairs (e.g. A-N; A-P or A-S) could be artefacts of scenario selection and should not be over interpreted (see also SI6). Interpreting production frontiers is only robust when it is supported by a similar interpretation of the cloud. This underlines the importance of using a large number of scenarios to build production frontiers and applying sensitivity analysis by adding or removing hypothetical landscapes and observing how results change.

With method 3, ES relationships inform us about the tradeoffs society must consider when preferring one efficient ES combination over another, and show which combination of pairs of ES are in fact impossible (everything above and to the right of the green line in Fig. 4). The revealed tradeoffs lead to reflection on societal preferences regarding what is efficient and desirable. The fact that most observed scenarios are far from Pareto efficient combination(s) confirms that landscape optimization rarely exists in reality, because of social constraints, actors preferences and path dependency (Bürgi et al., 2005; Nassauer, 1995; Schneeberger et al., 2007).

Our set of scenarios includes land-use configurations that are probably not acceptable to stakeholders. Another study on ES and landscape scenarios suggested that a full-restoration scenario may be of limited relevance to decision-makers, since it is regarded as unfeasible, but remains scientifically relevant as a benchmark to assess conservation efforts (Goldstein et al., 2012). The production frontier approach relies on the way we define plausible hypothetical scenarios and the possibility of including socially unacceptable scenarios.

There is a need to better integrate socio-cultural components in the assessment of ES tradeoffs (de Groot et al., 2010). Beyond the production frontier framework, we need to understand to what extent societal choices constrain land-use configuration and prevent the closer approach to Pareto efficient combinations (Tallis and Polasky, 2009). We also need to determine which efficient ES combinations could be preferred by stakeholders by assessing indifference curves that describe human preferences (Cavender-Bares et al., 2015; King et al., 2015; Kline and Mazzotta, 2012; Lester et al., 2013). Even though such preferences are difficult to assess (Lester et al., 2013), various methods have been developed to elicit preferences using tools from economics like stated or revealed preferences (Freeman et al., 2014) or from social sciences using interviews, focus groups, and other participatory approaches (King et al., 2015; MartínLópez et al., 2012). Preferences depend on the values and needs of each stakeholders or segment 
of society (Cavender-Bares et al., 2015; Hauck et al., 2013) as well as the processes of elicitation of preferences (i.e. individual or group deliberation) (Schleyer et al., 2015).

Different assessment methods focus on different dimensions of ES trade-offs (Martín-López et al., 2014) and make different explicit or implicit assumptions on what is important and how to measure it (Gasparatos, 2010). The choice of an assessment method is not neutral, it carries an underlying set of rules and judgments that influences the outcomes and the conclusions that can be drawn from them (Brondízio et al., 2010; Gomez-Baggethun and Ruiz-Perez, 2011; Vatn, 2009). ES practitioners and researchers should carefully check if the method selected is adequate for the policy question: for example, spatial correlations may contribute to defining spatial priorities (e.g. for ES hotspot protection or landscape multi-functionality promotion), temporal correlations to analyzing the implications of decisions on future ES changes, and production frontiers to setting landscape planning objectives.

The gap between science and policy may prevent the translation of ES knowledge into decisionmaking processes. Only 12 of the 105 publications analyzed by Laurans et al. (2013) looked at the decision context that supported the assessment of ES relationships. There is a risk that the outputs may be ignored by decision-makers if they do not match with what they need or expect (Gasparatos, 2010; Grêt-Regamey et al., 2016; Rosenthal et al., 2015). Improving knowledge about ES interaction means questioning the usefulness of different methods with respect to decision-making needs and expectations.

\section{Conclusion}

The objective of this study was to compare different methods for assessing ES relationships, using an example in Costa Rica. The methods we selected imply different assumptions about ES relationships and their quantification. Two methods (spatial and temporal correlations) relied on observed landscape configurations, and one (production frontiers) on simulated landscapes. The three methods showed different levels of sensitivity in detecting ES relationships. Interpreting spatial and temporal correlations is apparently straightforward, but the interpretation of production frontiers is more complex since it relies on several features of ES pair-plots: the shape, orientation and dispersal of the cloud of points, and the slope, shape and length of the frontier. All methods described similar tradeoffs between agricultural production and carbon sequestration. Some synergies between agricultural production and other 
services were also observed, suggesting that a general pattern of tradeoff between provisioning and regulating services should not be assumed without caution. Our analysis provides useful guidance on how to interpret production frontiers. As the three methods provide different contributions to decision-making on ES, it is recommended to choose methods in accordance with the decision context or to combine methods and compare their implications for decisionmaking.

\section{Acknowledgements}

This work was supported by the International Climate Initiative (IKI) of the German Federal Ministry for the Environment, Nature Conservation, Building and Nuclear Safety (BMUB), the European Union's Seventh Framework Programme for research, technological development and demonstration under grant agreement number 308393 (OPERAs project), the French Ministry of the Environment, Energy and Marine Affairs, and the CGIAR Research Program on Forests, Trees and Agroforestry (CRP-FTA) with financial support from the CGIAR Fund. The authors thank Christian Brenes Pérez, Pablo Imbach and Natalia Estrada Carmona for providing data on the case study, Alexandre Vallet and Thierry Brunelle for useful comments.

\section{Appendix A. Supplementary data}

Supplementary data to this article can be found online at https://doi.org/10.1016/j.ecolecon.2018.04.002. 


\section{References}

Avelino, J., Romero-Gurdián, A., Cruz-Cuellar, H.F., Declerck, F.A.J., 2012. Landscape context and scale differentially impact coffee leaf rust, coffee berry borer, and coffee root-knot nematodes. Ecol. Appl. Publ. Ecol. Soc. Am. 22, 584- 596 .

Bagstad, K.J., Semmens, D.J., Winthrop, R., 2013. Comparing approaches to spatially explicit ecosystem service modeling: a case study from the San Pedro River, Arizona. Ecosyst. Serv. 5, 40-50. http://dx.doi.org/10.1016/j.ecoser.2013.07.007.

Balvanera, P., Uriarte, M., Almeida-Leñero, L., Altesor, A., DeClerck, F., Gardner, T., Hall, J., Lara, A., Laterra, P., Peña-Claros, M., Silva Matos, D.M., Vogl, A.L., Romero-Duque, L.P., Arreola, L.F., Caro-Borrero, Á.P., Gallego, F., Jain, M., Little, C., de Oliveira Xavier, R., Paruelo, J.M., Peinado, J.E., Poorter, L., Ascarrunz, N., Correa, F., Cunha-Santino, M.B., Hernández-Sánchez, A.P., Vallejos, M., 2012. Ecosystem services research in Latin America: the state of the art. Ecosyst. Serv. 2, 56-70. http://dx.doi.org/10.1016/j.ecoser.2012.09.006.

Barber, C.B., Habel, K., Grasman, R., Gramacy, R.B., Stahel, A., Sterratt, D.C., 2015. Geometry: mesh generation and surface tesselation, R package version 0.3-6. https://cran.r-project.org/web/packages/geometry/index.html.

Bekele, E.G., Lant, C.L., Soman, S., Misgna, G., 2013. The evolution and empirical estimation of ecological-economic production possibilities frontiers. Ecol. Econ. 90, 1-9. http://dx.doi.org/10.1016/j.ecolecon.2013.02.012.

Bennett, E.M., Balvanera, P., 2007. The future of production systems in a globalized world. Front. Ecol. Environ. 5, 191-198.

Bennett, E.M., Peterson, G.D., Gordon, L.J., 2009. Understanding relationships among multiple ecosystem services: relationships among multiple ecosystem services. Ecol. Lett. 12, 1394-1404. http://dx.doi.org/10.1111/j.14610248.2009.01387.x.

Berthonnet, I., Delclite, T., 2014. Pareto-optimality or pareto-efficiency: same concept, different names? An analysis over a century of economic literature. In: Fiorito, L. (Ed.), Research in the History of Economic Thought and Methodology. Emerald Group Publishing Limited, pp. 129-145. http://dx.doi.org/10.1108/S0743415420140000032005.

Birkhofer, K., Diehl, E., Andersson, J., Ekroos, J., Früh-Müller, A., Machnikowski, F., Mader, V.L., Nilsson, L., Sasaki, K., Rundlöf, M., Wolters, V., Smith, H.G., 2015. Ecosystem services-current challenges and opportunities for ecological research. Front. Ecol. Evol. 2. http://dx.doi.org/10.3389/fevo.2014.00087 .

Bosselmann, A.S., 2012. Mediating factors of land use change among coffee farmers in a biological corridor. Ecol. Econ. 80, 79-88. http://dx.doi.org/10.1016/j.ecolecon.2012.05.007.

Brenes Pérez, C., 2009. Análisis multitemporal de cambio de uso de suelo y dinámica del paisaje en el Corredor Biológico Volcánica Central Talamanca, Costa Rica. CATIE, Turrialba, Costa Rica.

Brondízio, E.S., Gatzweiler, F.W., Zografos, C., Kumar, M., 2010. Socio-cultural context of ecosystem and biodiversity valuation. In: The Economics of Ecosystems and Biodiversity: Ecological and Economic Foundations. P. Kumar, London; Washington, DC, pp. 150-181.

Bürgi, M., Hersperger, A.M., Schneeberger, N., 2005. Driving forces of landscape change -current and new directions. Landsc. Ecol. 19, 857-868. http://dx.doi.org/10.1007/s10980-005-0245-3.

Cabral, P., Feger, C., Levrel, H., Chambolle, M., Basque, D., 2016. Assessing the impact of land-cover changes on ecosystem services: a first step toward integrative planning in Bordeaux, France. Ecosyst. Serv. 22, 318-327. http://dx.doi.org/10.1016/j.ecoser.2016.08.005. 
Carmona, N.E., DeClerck, F., 2012. Payment for ecosystem services for energy, biodiversity conservation, and poverty reduction in Costa Rica. In: Ingram, J.C., DeClerck, F., del Rio, C.R. (Eds.), Integrating Ecology and Poverty Reduction. Springer New York, pp. 191-210. http://dx.doi.org/10.1007/978-1-4614-0186-5_14.

Carpenter, S.R., Mooney, H.A., Agard, J., Capistrano, D., DeFries, R.S., Diaz, S., Dietz, T., Duraiappah, A.K., OtengYeboah, A., Pereira, H.M., Perrings, C., Reid, W.V., Sarukhan, J., Scholes, R.J., Whyte, A., 2009. Science for managing ecosystem services: beyond the millennium ecosystem assessment. Proc. Natl. Acad. Sci. 106, 13051312. http://dx.doi.org/10.1073/pnas.0808772106.

Casalegno, S., Inger, R., DeSilvey, C., Gaston, K.J., 2013. Spatial covariance between aesthetic value \& other ecosystem services. PLoS One 8, e68437. http://dx.doi.org/10.1371/journal.pone.0068437.

Caudill, S.A., DeClerck, F.J.A., Husband, T.P., 2015. Connecting sustainable agriculture and wildlife conservation: does shade coffee provide habitat for mammals? Agric. Ecosyst. Environ. 199, 85-93. http://dx.doi.org/10.1016/j.agee.2014.08.023.

Cavender-Bares, J., Polasky, S., King, E., Balvanera, P., 2015. A sustainability framework for assessing trade-offs in ecosystem services. Ecol. Soc. 20. http://dx.doi.org/10.5751/ES-06917-200117.

Chan, K.M.A., Shaw, M.R., Cameron, D.R., Underwood, E.C., Daily, G.C., 2006. Conservation planning for ecosystem services. PLoS Biol. 4, e379. http://dx.doi.org/10.1371/journal.pbio.0040379.

Clec'h, S.L., Oszwald, J., Decaens, T., Desjardins, T., Dufour, S., Grimaldi, M., Jegou, N., Lavelle, P., 2016. Mapping multiple ecosystem services indicators: toward an objective-oriented approach. Ecol. Indic. 69, 508-521. http://dx.doi.org/10.1016/j.ecolind.2016.05.021.

Cleff, T., 2014. Exploratory Data Analysis in Business and Economics. Springer International Publishing, Cham. http://dx.doi.org/10.1007/978-3-319-01517-0.

Cord, A.F., Bartkowski, B., Beckmann, M., Dittrich, A., Hermans-Neumann, K., Kaim, A., Lienhoop, N., LocherKrause, K., Priess, J., Schröter-Schlaack, C., Schwarz, N., Seppelt, R., Strauch, M., Václavík, T., Volk, M., 2017. Towards systematic analyses of ecosystem service trade-offs and synergies: main concepts, methods and the road ahead. Ecosyst. Serv. 28, 264-272. http://dx.doi.org/10.1016/j.ecoser.2017.07.012. (SI: Servicing ESEcoSummit16).

de Groot, R.S., Alkemade, R., Braat, L., Hein, L., Willemen, L., 2010. Challenges in integrating the concept of ecosystem services and values in landscape planning, management and decision making. Ecol. Complex. 7, 260-272. http://dx.doi.org/10.1016/j.ecocom.2009.10.006

Deng, X., Li, Z., Gibson, J., 2016. A review on trade-off analysis of ecosystem services for sustainable land-use management. J. Geogr. Sci. 26, 953-968. http://dx.doi.org/10. 1007/s11442-016-1309-9.

Dittrich, A., von Wehrden, H., Abson, D.J., Bartkowski, B., Cord, A.F., Fust, P., Hoyer, C., Kambach, S., Meyer, M.A., Radzevičiūtè, R., Nieto-Romero, M., Seppelt, R., Beckmann, M., 2017. Mapping and analysing historical indicators of ecosystem services in Germany. Ecol. Indic. 75, 101-110. http://dx.doi.org/10.1016/j.ecolind.2016.12.010.

Duinker, P.N., Greig, L.A., 2007. Scenario analysis in environmental impact assessment: improving explorations of the future. Environ. Impact Assess. Rev. 27, 206-219. http://dx.doi.org/10.1016/j.eiar.2006.11.001.

Edelsbrunner, H., Kirkpatrick, D., Seidel, R., 1983. On the shape of a set of points in the plane. IEEE Trans. Inf. Theory 29, 551-559. http://dx.doi.org/10.1109/TIT.1983.1056714.

Egoh, B., Reyers, B., Rouget, M., Richardson, D.M., Le Maitre, D.C., van Jaarsveld, A.S., 2008. Mapping ecosystem services for planning and management. Agric. Ecosyst. Environ. 127, 135-140. http://dx.doi.org/10.1016/j.agee.2008.03.013. 
ESRI, 2012. ArcGIS v10.1. ESRI, Redlands, California, US.

Estrada Carmona, N., 2009. Identificación de áreas prioritarias en la oferta de servicios ecosistémicos para establecer esquemas de Pagos (PSA) direccionados, Costa Rica. CATIE, Turrialba, Costa Rica.

Freeman, A.M., Herriges, J.A., Kling, C.L., 2014. The measurement of environmental and resource values: theory and methods, third edition. RFF Press, Abingdon, Oxon; New York, NY.

Gasparatos, A., 2010. Embedded value systems in sustainability assessment tools and their implications. J. Environ. Manag. 91, 1613-1622. https://doi.org/10.1016/j.jenvman.2010.03.014

Goldstein, J.H., Caldarone, G., Duarte, T.K., Ennaanay, D., Hannahs, N., Mendoza, G., Polasky, S., Wolny, S., Daily, G.C., 2012. Integrating ecosystem-service tradeoffs into land-use decisions. Proc. Natl. Acad. Sci. 109, 75657570. http://dx.doi.org/10.1073/pnas.1201040109.

Gomez-Baggethun, E., Ruiz-Perez, M., 2011. Economic valuation and the commodification of ecosystem services. Prog. Phys. Geogr. 35, 613-628. http://dx.doi.org/10.1177/0309133311421708.

Gos, P., Lavorel, S., 2012. Stakeholders' expectations on ecosystem services affect the assessment of ecosystem services hotspots and their congruence with biodiversity. Int. J. Biodivers. Sci. Ecosyst. Serv. Manag. 8, 93-106. http://dx.doi.org/10.1080/21513732.2011.646303.

Grêt-Regamey, A., Sirén, E., Brunner, S.H., Weibel, B., 2016. Review of decision support tools to operationalize the ecosystem services concept. Ecosyst. Serv. http://dx.doi.org/10.1016/j.ecoser.2016.10.012.

Groot, J.C.J., Oomen, G.J.M., Rossing, W.A.H., 2012. Multi-objective optimization and design of farming systems. Agric. Syst. 110, 63-77. http://dx.doi.org/10.1016/j.agsy.2012.03.012.

Haase, D., Schwarz, N., Strohbach, M., Kroll, F., Seppelt, R., 2012. Synergies, trade-offs, and losses of ecosystem services in urban regions: an integrated multiscale framework applied to the Leipzig-Halle Region, Germany. Ecol. Soc. 17. http://dx.doi.org/10. 5751/ES-04853-170322.

Haines-Young, R., Potschin, M., Kienast, F., 2012. Indicators of ecosystem service potential at European scales: mapping marginal changes and trade-offs. Ecol. Indic. 21, 39-53. http://dx.doi.org/10.1016/j.ecolind.2011.09.004.

Hauck, J., Görg, C., Varjopuro, R., Ratamäki, O., Jax, K., 2013. Benefits and limitations of the ecosystem services concept in environmental policy and decision making: some stakeholder perspectives. Environ. Sci. Pol. 25, 13-21. http://dx.doi.org/10.1016/j.envsci.2012.08.001.

Hauer, G., Cumming, S., Schmiegelow, F., Adamowicz, W.L., Weber, M., Jagodzinski, R., 2007. Tradeoffs Between Forestry Resource and Conservation Values Under Alternate Forest Policy Regimes: A Spatial Analysis of the Western Canadian Boreal Plains (Staff Paper Series No. 52086). University of Alberta, Department of Resource Economics and Environmental Sociology.

Hijmans, R.J., Cameron, S.E., Parra, J.L., Jones, P.G., Jarvis, A., 2005. Very high resolution interpolated climate surfaces for global land areas. Int. J. Climatol. 25, 1965-1978. http://dx.doi.org/10.1002/joc.1276.

Hijmans, R.J., van Etten, J., Mattiuzzi, M., Sumner, M., Greenberg, J.A., Lamigueiro, O.P., Bevan, A., Racine, E.B., Shortridge, A., 2015. Raster: Geographic Data Analysis and Modeling, R Package Version 2.3-24. http://cran.rproject.org/web/packages/raster/index.html.

Imbach, P., Molina, L., Locatelli, B., Roupsard, O., Ciais, P., Corrales, L., Mahé, G., 2010. Climatology-based regional modelling of potential vegetation and average annual long-term runoff for Mesoamerica. Hydrol. Earth Syst. Sci. 14, 1801-1817. http://dx.doi.org/10.5194/hess-14-1801-2010.

IPBES, 2016. The methodological assessment report on scenarios and models of biodiversity and ecosystem services. In: Ferrier, S., Ninan, K.N., Leadley, P., Alkemade, R., Acosta, L.A., Akçakaya, H.R., Brotons, L., Cheung, 
W.W.L., Christensen, V., Harhash, K.A., Kabubo-Mariara, J., Lundquist, C., Obersteiner, M., Pereira, H.M., Peterson, G., Pichs-Madruga, R., Ravindranath, N., Rondinini, C., Wintle, B.A. (Eds.), Secretariat of the Intergovernmental Science-Policy Platform on Biodiversity and Ecosystem Services, Bonn, Germany.

ITCR, 2004. Digital Atlas of Costa Rica: CD-Rom. Instituto Tecnológico de Costa Rica, Cartago, Costa Rica.

Jopke, C., Kreyling, J., Maes, J., Koellner, T., 2015. Interactions among ecosystem services across Europe: Bagplots and cumulative correlation coefficients reveal synergies, trade-offs, and regional patterns. Ecol. Indic. 49, 4652. http://dx.doi.org/10.1016/j.ecolind.2014.09.037.

King, E., Cavender-Bares, J., Balvanera, P., Mwampamba, T., Polasky, S., 2015. Trade-offs in ecosystem services and varying stakeholder preferences: evaluating conflicts, obstacles, and opportunities. Ecol. Soc. 20. http://dx.doi.org/10.5751/ES-07822-200325.

Kline, J.D., Mazzotta, M.J., 2012. Evaluating Tradeoffs Among Ecosystem Services in the Management of Public Lands (General Technical Report No. PNW-GTR-865). Department of Agriculture, Forest Service, Pacific Northwest Research Station, Portland, OR: US.

Laurans, Y., Rankovic, A., Billé, R., Pirard, R., Mermet, L., 2013. Use of ecosystem services economic valuation for decision making: questioning a literature blindspot. J. Environ. Manag. 119, 208-219. http://dx.doi.org/10.1016/j.jenvman.2013.01.008.

Lautenbach, S., Volk, M., Strauch, M., Whittaker, G., Seppelt, R., 2013. Optimization-based trade-off analysis of biodiesel crop production for managing an agricultural catchment. Environ. Model. Softw. 48, 98-112. http://dx.doi.org/10.1016/j.envsoft.2013.06.006.

Lautenbach, S., Mupepele, A.-C., Dormann, C.F., Lee, H., Schmidt, S., Scholte, S.S.K., Seppelt, R., van Teeffelen, A.J.A., Verhagen, W., Volk, M., 2015. Blind spots in ecosystem services research and implementation. bioRxiv, 033498. http://dx.doi.org/10.1101/033498.

Lavorel, S., Grigulis, K., Lamarque, P., Colace, M.-P., Garden, D., Girel, J., Pellet, G., Douzet, R., 2011. Using plant functional traits to understand the landscape distribution of multiple ecosystem services. J. Ecol. 99, 135-147. http://dx.doi.org/10.1111/j.1365-2745.2010.01753.x.

LeBlanc, D.C., 2004. Statistics: Concepts and Applications for Science. Jones \& Bartlett Learning.

Lee, H., Lautenbach, S., 2016. A quantitative review of relationships between ecosystem services. Ecol. Indic. 66, 340351. http://dx.doi.org/10.1016/j.ecolind.2016.02.004.

Lester, S.E., Costello, C., Halpern, B.S., Gaines, S.D., White, C., Barth, J.A., 2013. Evaluating tradeoffs among ecosystem services to inform marine spatial planning. Mar. Policy 38, 80-89. http://dx.doi.org/10.1016/j.marpol.2012.05.022.

Levrel, H., Cabral, P., Feger, C., Chambolle, M., Basque, D., 2017. How to overcome the implementation gap in ecosystem services? A user-friendly and inclusive tool for improved urban management. Land Use Policy 68, 574-584. http://dx.doi.org/10.1016/j.landusepol.2017.07.037.

Locatelli, B., Imbach, P., Vignola, R., Metzger, M.J., Hidalgo, E.J.L., 2011. Ecosystem services and hydroelectricity in Central America: modelling service flows with fuzzy logic and expert knowledge. Reg. Environ. Chang. 11, 393-404. http://dx.doi.org/10.1007/s10113-010-0149-x.

Locatelli, B., Imbach, P., Wunder, S., 2014. Synergies and trade-o ffs between ecosystem services in Costa Rica. Environ. Conserv. 41, 27-36. http://dx.doi.org/10.1017/S0376892913000234.

Locatelli, B., Lavorel, S., Sloan, S., Tappeiner, U., Geneletti, D., 2017. Archetypes of trajectories of ecosystem services in mountains. Front. Ecol. Environ. http://dx.doi.org/10.1002/fee.1470. 
Maes, J., Paracchini, M.L., Zulian, G., Dunbar, M.B., Alkemade, R., 2012. Synergies and trade-offs between ecosystem service supply, biodiversity, and habitat conservation status in Europe. Biol. Conserv. 155, 1-12. http://dx.doi.org/10.1016/j.biocon.2012.06.016.

Manache, G., Melching, C.S., 2004. Sensitivity analysis of a water-quality model using Latin hypercube sampling. J. Water Resour. Plan. Manag. 130, 232-242. http://dx.doi.org/10.1061/(ASCE)0733-9496(2004)130:3(232).

Martinez-Harms, M.J., Bryan, B.A., Balvanera, P., Law, E.A., Rhodes, J.R., Possingham, H.P., Wilson, K.A., 2015. Making decisions for managing ecosystem services. Biol. Conserv. 184, 229-238. http://dx.doi.org/10.1016/j.biocon.2015.01.024.

Martín-López, B., Iniesta-Arandia, I., García-Llorente, M., Palomo, I., Casado-Arzuaga, I., Amo, D.G.D., GómezBaggethun, E., Oteros-Rozas, E., Palacios-Agundez, I., Willaarts, B., González, J.A., Santos-Martín, F., Onaindia, M., López-Santiago, C., Montes, C., 2012. Uncovering ecosystem service bundles through social preferences. PLoS One 7, e38970. http://dx.doi.org/10.1371/journal.pone.0038970 .

Martín-López, B., Gómez-Baggethun, E., García-Llorente, M., Montes, C., 2014. Trade-offs across value-domains in ecosystem services assessment. Ecol. Indic. 37, 220-228. http://dx.doi.org/10.1016/j.ecolind.2013.03.003.

McKenzie, E., Posner, S., Tillmann, P., Bernhardt, J.R., Howard, K., Rosenthal, A., 2014. Understanding the use of ecosystem service knowledge in decision making: lessons from international experiences of spatial planning. Eviron. Plann. C. Gov. Policy 32, 320-340. http://dx.doi.org/10.1068/c12292j.

Mersmann, O., 2012. emoa: Evolutionary Multiobjective Optimization Algorithms, R package version 0.5-0. https://cran.r-project.org/web/packages/emoa/index.html

Minang, P.A., van Noordwijk, M., Freeman, O.E., Mbow, C., de Leeuw, J., Catacutan, D., 2014. Climate-Smart Landscapes: Multifunctionality in Practice. World Agroforestry Centre (ICRAF), Nairobi, Kenya.

Mouchet, M.A., Lamarque, P., Martín-López, B., Crouzat, E., Gos, P., Byczek, C., Lavorel, S., 2014. An interdisciplinary methodological guide for quantifying associations between ecosystem services. Glob. Environ. Chang. 28, 298-308. http://dx.doi.org/10.1016/j.gloenvcha.2014.07.012.

NASA LP, D.A.A.C., 2011. ASTER Global Digital Elevation Model Version 2. USGS/EROS center, Sioux Falls, South Dakota.

Nassauer, J.I., 1995. Culture and changing landscape structure. Landsc. Ecol. 10, $229-237$. http://dx.doi.org/10.1007/BF00129257.

Nelson, E., Polasky, S., Lewis, D.J., Plantinga, A.J., Lonsdorf, E., White, D., Bael, D., Lawler, J.J., 2008. Efficiency of incentives to jointly increase carbon sequestration and species conservation on a landscape. Proc. Natl. Acad. Sci. 105, 9471-9476. http://dx.doi.org/10.1073/pnas.0706178105.

Nelson, E., Mendoza, G., Regetz, J., Polasky, S., Tallis, H., Cameron, Dr., Chan, K.M., Daily, G.C., Goldstein, J., Kareiva, P.M., Lonsdorf, E., Naidoo, R., Ricketts, T.H., Shaw, Mr, 2009. Modeling multiple ecosystem services, biodiversity conservation, commodity production, and tradeoffs at landscape scales. Front. Ecol. Environ. 7, 4-11. http://dx.doi.org/10.1890/080023.

Nemec, K.T., Raudsepp-Hearne, C., 2012. The use of geographic information systems to map and assess ecosystem services. Biodivers. Conserv. 22, 1-15. http://dx.doi.org/10.1007/s10531-012-0406-z.

Pateiro-Lopez, B., Rodriguez-Casal, A., 2016. alphahull: Generalization of the Convex Hull of a Sample of Points in the Plane, R Package Version 2.1. https://cran.r-project.org/web/packages/alphahull/index.html.

Peterson, G.D., Cumming, G.S., Carpenter, S.R., 2003. Scenario planning: a tool for conservation in an uncertain world. Conserv. Biol. 17, 358-366. http://dx.doi.org/10.1046/j.1523-1739.2003.01491.x. 
Polasky, S., Nelson, E., Camm, J., Csuti, B., Fackler, P., Lonsdorf, E., Montgomery, C., White, D., Arthur, J., GarberYonts, B., Haight, R., Kagan, J., Starfield, A., Tobalske, C., 2008. Where to put things? Spatial land management to sustain biodiversity and economic returns. Biol. Conserv. 141, 1505-1524. http://dx.doi.org/10.1016/j.biocon.2008.03.022.

Polasky, S., Nelson, E., Pennington, D., Johnson, K.A., 2011. The impact of land-use change on ecosystem services, biodiversity and returns to landowners: a case study in the State of Minnesota. Environ. Resour. Econ. 48, 219242. http://dx.doi.org/10.1007/s10640-010-9407-0.

PREVDA, 2008. Plan de cuenca del río Reventazón-Parismina 2008-2010. Turrialba, Costa Rica.

Qiu, J., Turner, M.G., 2013. Spatial interactions among ecosystem services in an urbanizing agricultural watershed. Proc. Natl. Acad. Sci. 110, 12149 -12154. http://dx.doi.org/10.1073/pnas.1310539110.

R Core Team, 2016. R: A Language and Environment for Statistical Computing, Version 3.3.2. R Foundation for Statistical Computing, Vienna, Austria

Raudsepp-Hearne, C., Peterson, G.D., Bennett, E.M., 2010. Ecosystem service bundles for analyzing tradeoffs in diverse landscapes. Proc. Natl. Acad. Sci. 107, 5242-5247. http://dx.doi.org/10.1073/pnas.0907284107.

Renard, D., Rhemtulla, J.M., Bennett, E.M., 2015. Historical dynamics in ecosystem service bundles. Proc. Natl. Acad. Sci. 112, 13411-13416. http://dx.doi.org/10.1073/pnas.1502565112.

Rodríguez, J.P., Beard, T.D., Bennett, E.M., Cumming, G.S., Cork, S.J., Agard, J., Dobson, A.P., Peterson, G.D., 2006. Trade-offs across space, time, and ecosystem services. Ecol. Soc. 11, 28.

Rosenthal, A., Verutes, G., McKenzie, E., Arkema, K.K., Bhagabati, N., Bremer, L.L., Olwero, N., Vogl, A.L., 2015. Process matters: a framework for conducting decision-relevant assessments of ecosystem services. Int. J. Biodivers. Sci. Ecosyst. Serv. Manag. 11, 190-204. http://dx.doi.org/10.1080/21513732.2014.966149.

Ruijs, A., Wossink, A., Kortelainen, M., Alkemade, R., Schulp, C.J.E., 2013. Trade-off analysis of ecosystem services in Eastern Europe. In: Ecosyst. Serv., Special Issue on Mapping and Modelling Ecosystem Services. 4. pp. 8294. http://dx.doi.org/10.1016/j.ecoser.2013.04.002.

Schleyer, C., Görg, C., Hauck, J., Winkler, K.J., 2015. Opportunities and challenges for mainstreaming the ecosystem services concept in the multi-level policy-making within the EU. Ecosyst. Serv. 16, 174-181. http://dx.doi.org/10.1016/j.ecoser.2015.10.014.

Schneeberger, N., Bürgi, M., Hersperger, A.M., Ewald, K.C., 2007. Driving forces and rates of landscape change as a promising combination for landscape change research — an application on the northern fringe of the Swiss alps. Land Use Policy 24, 349-361. http://dx.doi.org/10.1016/j.landusepol.2006.04.003.

Seppelt, R., Voinov, A., 2002. Optimization methodology for land use patterns using spatially explicit landscape models. Ecol. Model. 151, 125-142. http://dx.doi.org/10.1016/S0304-3800(01)00455-0.

Seppelt, R., Voinov, A., 2003. Optimization methodology for land use patterns-evaluation based on multiscale habitat pattern comparison. Ecol. Model. 168, 217-231. http://dx.doi.org/10.1016/S0304-3800(03)00138-8.

Seppelt, R., Dormann, C.F., Eppink, F.V., Lautenbach, S., Schmidt, S., 2011. A quantitative review of ecosystem service studies: approaches, shortcomings and the road ahead: priorities for ecosystem service studies. J. Appl. Ecol. 48, 630-636. http://dx.doi.org/10.1111/j.1365-2664.2010.01952.x .

Seppelt, R., Lautenbach, S., Volk, M., 2013. Identifying trade-offs between ecosystem services, land use, and biodiversity: a plea for combining scenario analysis and optimization on different spatial scales. Curr. Opin. Environ. Sustain. 5, 458-463. http://dx.doi.org/10.1016/j.cosust.2013.05.002.

Seppelt, R., Manceur, A., Liu, J., Fenichel, E., Klotz, S., 2014. Synchronized peak-rate years of global resources use. Ecol. Soc. 19. http://dx.doi.org/10.5751/ES-07039-190450. 
Smith, F.P., Gorddard, R., House, A.P.N., McIntyre, S., Prober, S.M., 2012. Biodiversity and agriculture: production frontiers as a framework for exploring trade-offs and evaluating policy. Environ. Sci. Pol. 23, 85-94. http://dx.doi.org/10.1016/j.envsci.2012.07.013.

Swallow, B.M., Sang, J.K., Nyabenge, M., Bundotich, D.K., Duraiappah, A.K., Yatich, T.B., 2009. Tradeoffs, synergies and traps among ecosystem services in the Lake Victoria basin of East Africa. Environ. Sci. Pol. 12, 504-519. http://dx.doi.org/10.1016/j.envsci.2008.11.003.

Tallis, H., Polasky, S., 2009. Mapping and valuing ecosystem services as an approach for conservation and naturalresource management. Ann. N. Y. Acad. Sci. 1162, 265-283. http://dx.doi.org/10.1111/j.17496632.2009.04152.x.

TEEB, 2010. The Economics of Ecosystems and Biodiversity Ecological and Economic Foundations. Pushpam Kumar, Earthscan, London and Washington.

Tomscha, S., Gergel, S., 2016. Ecosystem service trade-offs and synergies misunderstood without landscape history. Ecol. Soc. 21. http://dx.doi.org/10.5751/ES-08345-210143.

Tourki, Y., Keisler, J., Linkov, I., 2013. Scenario analysis: a review of methods and applications for engineering and environmental systems. Environ. Syst. Decis. 33, 3-20. http://dx.doi.org/10.1007/s10669-013-9437-6.

Turkelboom, F., Leone, M., Jacobs, S., Kelemen, E., García-Llorente, M., Baró, F., Termansen, M., Barton, D.N., Berry, P., Stange, E., Thoonen, M., Kalóczkai, Á., Vadineanu, A., Castro, A.J., Czúcz, B., Röckmann, C., Wurbs, D., Odee, D., Preda, E., Gómez-Baggethun, E., Rusch, G.M., Pastur, G.M., Palomo, I., Dick, J., Casaer, J., van Dijk, J., Priess, J.A., Langemeyer, J., Mustajoki, J., Kopperoinen, L., Baptist, M.J., Peri, P.L., Mukhopadhyay, R., Aszalós, R., Roy, S.B., Luque, S., Rusch, V., 2017. When we cannot have it all: ecosystem services tradeoffs in the context of spatial planning. Ecosyst. Serv. http://dx.doi.org/10.1016/j.ecoser.2017.10.011.

Turner, M.G., Donato, D.C., Romme, W.H., 2013. Consequences of spatial heterogeneity for ecosystem services in changing forest landscapes: priorities for future research. Landsc. Ecol. 28, 1081-1097. http://dx.doi.org/10.1007/s10980-012-9741-4.

Turner, K.G., Odgaard, M.V., Bøcher, P.K., Dalgaard, T., Svenning, J.-C., 2014. Bundling ecosystem services in Denmark: trade-offs and synergies in a cultural landscape. Landsc. Urban Plan. 125, 89-104. http://dx.doi.org/10.1016/j.landurbplan.2014.02.007.

Vallet, A., Locatelli, B., Levrel, H., Pérez, C.B., Imbach, P., Carmona, N.E., Manlay, R., Oszwald, J., 2016. Dynamics of ecosystem services during forest transitions in Reventazón, Costa Rica. PLoS One 11, e0158615. http://dx.doi.org/10.1371/journal.pone.0158615.

van Wijk, M.T., Klapwijk, C.J., Rosenstock, T.S., van Asten, P.J.A., Thornton, P.K., Giller, K.E., 2016. Methods for Environment: Productivity Trade-off Analysis in Agricultural Systems, in: Methods for Measuring Greenhouse Gas Balances and Evaluating Mitigation Options in Smallholder Agriculture. Springer, Cham, pp. 189-198. http://dx.doi.org/10.1007/978-3-319-29794-1_10.

Varian, H.R., 2010. Intermediate Microeconomics: A Modern Approach, 8th ed. W.W. Norton \& Co, New York.

Vatn, A., 2009. An institutional analysis of methods for environmental appraisal. Ecol. Econ. 68, $2207-2215$. http://dx.doi.org/10.1016/j.ecolecon.2009.04.005.

Vigl, L.E., Schirpke, U., Tasser, E., Tappeiner, U., 2016. Linking long-term landscape dynamics to the multiple interactions among ecosystem services in the European Alps. Landsc. Ecol. 31, 1903-1918. http://dx.doi.org/10.1007/s10980-016-0389-3. 
White, C., Halpern, B.S., Kappel, C.V., 2012. Ecosystem service tradeoff analysis reveals the value of marine spatial planning for multiple ocean uses. Proc. Natl. Acad. Sci. 109, 4696-4701. http://dx.doi.org/10.1073/pnas.1114215109.

Wickham, H., Chang, W., RStudio, 2016. ggplot2: create elegant data visualisations using the grammar of graphics, R package version 2.2.1. https://cran.r-project.org/web/packages/ggplot2/index.html.

Willemen, L., Hein, L., van Mensvoort, M.E., Verburg, P.H., 2010. Space for people, plants, and livestock? Quantifying interactions among multiple landscape functions in a Dutch rural region. Ecol. Indic. 10, 62-73.

Wossink, A., Swinton, S.M., 2007. Jointness in production and farmers' willingness to supply non-marketed ecosystem services. Ecol. Econ. 64, 297-304. http://dx.doi.org/10.1016/j.ecolecon.2007.07.003.

Yapo, P.O., Gupta, H.V., Sorooshian, S., 1998. Multi-objective global optimization for hydrologic models. J. Hydrol. 204, 83-97. http://dx.doi.org/10.1016/S0022-1694(97)00107-8.

Zheng, Z., Fu, B., Hu, H., Sun, G., 2014. A method to identify the variable ecosystem services relationship across time: a case study on Yanhe Basin, China. Landsc. Ecol. 29, 1689-1696. http://dx.doi.org/10.1007/s10980-0140088-X 